\title{
Relationship Between Exchange Rate and Trade Balance: "The Case of Albania"
}

\author{
Alban Korbi \\ Doc. Dr, Faculty of Economy, University of Tirana \\ Benarda Banushaj \\ MSc. Finance, Faculty of Economy, University of Tirana
}

\section{Abstract}

This paper analyzes the relationship that exists between the trade balance and the exchange rate. For a clearer picture of the results, other macroeconomic factors that are thought to have an impact on the trade balance, such as economic growth, trade openness, foreign direct investment, and remittances are analyzed. The main objective of this paper is to empirically identify the impact that exchange rate volatility has on the trade balance, specifically Albania. The study uses data obtained from the World Bank and INSTAT for the period 2000-2018. The method used is the empirical method in presenting the facts and the performance of macroeconomic factors and the econometric method in analyzing the relationship between the exchange rate and the trade opening. The VAR model was used to estimate the regression results and the evaluation procedure for the parameters is time series, using data on trade as a percentage of GDP, Euro / ALL exchange rate, foreign direct investment, economic growth, and remittances. The results of this study show that in the case of the Republic of Albania according to the VAR model there is no stable relationship between the exchange rate and trade.

Keywords: Albania, exchange rate, trade balance, VAR test

JEL Classification: F11, F14, F31

\section{Introduction}

Many studies have been done to assess the impact of the exchange rate on the trade balance. The exchange rate reflects all transactions between economic agents, at home and abroad. Imports, exports and investments in domestic and foreign financial assets, not only affect the exchange rate, but also affect its current and expected values. 
The real exchange rate indirectly affects the distribution of resources in the economy, tradable and non-tradable goods and consequently the trade balance. The purpose of this paper is to identify the role of the exchange rate in Albania's trade balance.

In the first part of this paper we will analyze the latest macroeconomic developments in terms of trade balance as well as theoretical and empirical assessments of the relationship between the exchange rate and trade balance. In the next section we will describe the performance of the trade balance in Albania for the last decades, an empirical summary of the facts and the performance of the trade balance and other macroeconomic factors over the years. The paper concludes with the econometric model based on the VAR test which aims to explain a possible relationship between trade as a percentage of GDP and the Euro / ALL exchange rate.

\section{Literature Review}

When assessing the impact of the exchange rate on the trade balance it is important to rely on the theories identified. Given the theoretical view that shows the relationship between the exchange rate and the trade balance, attempts have been made to analyze this impact through empirical studies.

A study that tested the bilateral J-curve effects for three transitional central European countries, namely Czech Republic, Hungary and Poland, and their bilateral trade with Germany was conducted by Hacker and Hatemi-J (2004), in their study. The trade balances are calculated as a ratio of exports to imports, and they are explained by bilateral real exchange rates and domestic and foreign income levels. Using a vector error correction model (VECM) and impulse response functions, the study finds that the J-curve effect is observed for each of the countries as the trade balances briefly deteriorate after a depreciation in the real exchange rate and then improve in the long run. (Hacker.R.S ; Hatemi-J.A)

The effect of depreciation on the trade balance of eleven Central and Eastern European countries was investigated by Bahmani-Oskooee and Kutan (2006). The study implemented the cointegration approach and error-correction modeling using quarterly data from 1990 to 2005 . The results showed the presence of J-curves in the cases of Russia, Croatia and Bulgaria. (Bahmani \& Kutan, 2006).

Salko and Osmani analyzed the time series of exports and imports only in relation to current and past exchange rate data. They find a potential impact of depreciation on exports but not on imports. (Salko \& Osmani, 2002)

(Sojlli \& Shtylla, 2006) have concluded that the exchange rate is an important macroeconomic variable for the short-term performance of imports in Albania, but not exports, and that in the long run the exchange rate has a greater impact than GDP.

Another author investigated the effect of exchange rate depreciation on Albania's trade balance. (HODA, 2013) The study used quarterly data from 1998 to 2012 and the results showed that the exchange rate effect is present in exports and has a 
significant impact on trade deficit reduction and revenues have a significant impact on trade flows.

(Cakrani, 2014) after studied the impact of the exchange rate on several macroeconomic variables in Albania (including exports and imports) concluded that the real ecxhange rate does not have a significant impact on the Albanian economy.

Many studies have been done in Albania but also in different countries to discover the relationship between the exchange rate and the trade balance and in many cases they present different results. Based on the contradictory conclusions that exist regarding this issue, this paper aims to contribute to clarifying the position of the real exchange rate in the trade balance.

\section{Macroeconomic Factors in Albania}

As it is known, since the beginning of the transition, Albania has adopted a flexible exchange rate regime. This means that the price of foreign currencies, even the euro against the Albanian lek is determined by the conditions of the foreign exchange market. Exchange rate fluctuations reflect the free movement of goods and monetary capital in Albania's trade and financial exchanges with its trading partners.

\section{Exchange Rate}

During the period 2000-2018 the exchange rate has had high volatility, we have both appreciation and devaluation of the ALL against the euro and the dollar. Fluctuations in the exchange rate of the ALL against the euro and the US dollar are also reflected in the Albanian trade balance. Therefore, it is important to note that Albania, like other countries in Southeast Europe, recorded a negative trade balance in the period 20002018.

\section{Trade}

The ratio of trade to GDP is an indicator of the relative importance of international trade in a country's economy. In Albania, trade has always occupied a significant part of GDP. From 2000-2018 the share of trade in GDP has been increasing from 60 percent of GDP already about 80 percent of GDP.

\section{Foreign Direct Investment}

Foreign Direct Investment (FDI) is a very important source of capital financing in small economies, such as Albania. In Albania, FDI appeared after the 1990s with the change of the political system and their level was low. But after the 2000s their volume began to increase significantly as the country offered great opportunities for foreign investors, not only for the many untapped resources in almost every economic sector but also because the implemented political system followed the path of privatizations in the sectors of energy, telecommunications, services, infrastructure and especially airlines, etc. The main investors in Albania are the countries of the European Union 


\section{Remittances}

Remittances, according to Bank of Albania estimates, constitute the largest inflow into the Albanian economy, leaving behind foreign direct investment and exports. They have been the most stable and secure financial flow in the Albanian economy, over the years affecting the improvement of the balance of payments and the level of economic development in the country. (An overview of remittances, 2019). Since 2006 the level of remittances has been decreasing and their lowest level was during 2012-2014 as a result of the economic crisis affecting neighboring countries like Greece and Italy in which the level of population migration is higher. This difficult situation is also reflected in the reduction of the country's GDP.

\section{Econometric Model}

This research aims to determine the relationship that exists between the trade balance, the exchange rate, foreign direct investment, economic growth, and remittances. The choice of variables is based on the analysis of various kinds of literature that have studied the relationship that exists between the trade balance and macroeconomic factors. In this paper, the regression model is built based on the described conceptual framework and is adapted only for Albania.

Trade $=\beta_{0}+\beta$ ER $+\beta$ FDI $+\beta$ GDP $+\beta$ REM $+\varepsilon$

Trade- represents trade as a percentage of GDP. It is an indicator of the relative importance of international trade in a country's economy. It is calculated by dividing the aggregate value of imports and exports over a period by gross domestic product for the same period. Although called a ratio, it is usually expressed as a percentage. It is used as a measure of a country's opening in international trade, and so it can be called the trade opening ratio.

ER- represents the Euro / ALL exchange rate. The value of the ALL against foreign currencies is freely determined in the foreign exchange market. Exchange rate fluctuations reflect the free movement of goods and capital in Albania's trade and financial exchanges with its trading partners.

FDI- Foreign direct investment as a percentage of GDP. Is a category of investment by resident enterprises (direct investor) in an economy, with long-term business interest in another economy from the country of origin of the direct investor, expressed as a percentage of GDP.

GDP (Gross Domestic Product) - represents the total cash value of all goods and services produced during a specific period by resident production units. Economic growth occurs when the market value of products and services in one economy increases in one period compared to another.

REM-remittances as a percentage of GDP. Remittances are defined as the sum of two components: income from work and personal transfers. Personal remittances 
received as a share of GDP are the flow of personal remittances expressed as a percentage of Gross Domestic Product (GDP)

Descriptive Analysis

Table 1: Descriptive Statistics

$\begin{array}{llllll} & \text { TRADE } & \text { ER } & \text { FDI } & \text { GDP } & \text { REM } \\ \text { Mean } & 65.45108 & 132.7368 & 6.500064 & 4.623970 & 13.51915 \\ \text { Median } & 70.87253 & 134.0000 & 7.453973 & 3.841364 & 13.71852 \\ \text { Maximum } & 85.02975 & 140.0000 & 11.16018 & 13.50117 & 17.22092 \\ \text { Minimum } & 45.87242 & 122.0000 & 1.206527 & 1.000755 & 10.03355 \\ \text { Std. Dev. } & 8.42145 & 6.781037 & 2.917301 & 2.859078 & 2.379445 \\ \text { Skewness } & -1.192750 & -0.421614 & -0.191790 & 1.511258 & -0.025496 \\ \text { Kurtosis } & 3.276237 & 1.616951 & 1.733029 & 5.931555 & 1.588475 \\ \text { Jarque-Bera } & 3.423051 & 2.077220 & 1.387276 & 14.03594 & 1.579378 \\ \text { Probability } & 0.180590 & 0.353946 & 0.499755 & 0.000896 & 0.453986 \\ \text { Sum } & 1346.382 & 2522.000 & 123.5012 & 87.85542 & 256.8639 \\ \text { Sum Sq. Dev. } & 1519.916 & 827.6842 & 153.1916 & 147.1379 & 101.9116 \\ \text { Observations } & 19 & 19 & 19 & 19 & 19\end{array}$

The results from the descriptive statistics table can help give an idea best overall data by looking at a minimum, maximum, and values average for each. It can also be seen that ER, IHD, and REM have values of skewness close to zero and kurtosis less than 3 while Trade and GDP have respective values away 0 and 3.

\section{ADF Unit Root Test}

Initially constructing an equation on variables seems to give a model of power good explanatory with a regulated R2 of 66 percent and its overall importance high. However, time-series data can often present false results as a consequence of nonstationary data or otherwise called false regressions. This is the reason why further tests are needed to create an accurate model that gives relationships between variables.

To check for data stationarity will be used Augmented Dickey-Fuller test. Hypothesis zero for this test indicates that the unit root is present in the data. Any variable tested separately and the results can be seen in the appendices. When testing for variables is done in their level form, all of them except GDP, have high probability values therefore fail to refute the hypothesis base, which means that time series data is nonstationary. To continue testing is done for their first form of change and it helps to convert data from non-stationary to stationary. The analysis is then continued with the VAR method as we have ensured that all variables are stationary. 


\section{Heteroskedasticity Test}

The problem of heteroskedasticity makes econometric analysis irrelevant. In order to proceed with the other steps, the heteroskedasticity test must first be performed. The Breusch-Pagan-Godfrey test show a p value for Obs * R-squared of 0.9 which it is not important, therefore the data are homoskedastic.

\section{Heteroskedasticity Test: Breusch-Pagan-Godfrey}

\begin{tabular}{lrlr}
\hline \hline F-statistic & 0.084071 & Prob. F(4,14) & 0.8974 \\
Obs*R-squared & 0.450734 & Prob. Chi-Square(4) 0.9772 \\
Scaled explained SS 0.204842 & Prob. Chi-Square(4) 0.9856
\end{tabular}

\section{VAR Model}

VAR models are a well-known method for the multivariate time series, like that of this study. For VAR models to be applied the variables must be stationary. This is why the first change is taken for all variables except GDP which was stationary at the level so there is no need for transformation. The lag length number must first be determined, which is done using the lag length criteria option. From the tests done based on the criterion of the lowest values of AIC and BIC, the optimal number of delays to be used is 2 .

After determining the optimal number of lag length proceed with the VAR model. Before analyzing the results, another test for the model should be done. According to the VAR model, trade and exchange rate have an inverse relationship but this relationship is not important in both Lag 1 and Lag 2 . Therefore it can be said that in the VAR, there are no clear and strong relationships between the variables.

\section{VAR Test}

Vector Autoregression Estimates

Date: $11 / 01 / 20 \quad$ Time: 19:58

Sample (adjusted): 20032018

Included observations: 16 after adjustments

Standard errors in ( ) \& t-statistics in [ ]

$\begin{array}{llll}T R A D E & D E R & D F D I & \text { DREM }\end{array}$




\begin{tabular}{|c|c|c|c|c|c|}
\hline$T R A D E(-1)$ & $\begin{array}{l}0.272403 \\
(0.60134) \\
{[0.50835]}\end{array}$ & $\begin{array}{l}-0.033461 \\
(0.29851) \\
{[-0.13886]}\end{array}$ & $\begin{array}{l}-0.031411 \\
(0.19213) \\
{[-0.16171]}\end{array}$ & $\begin{array}{l}0.095102 \\
(0.09102) \\
{[1.17451]}\end{array}$ & $\begin{array}{l}-0.074564 \\
(0.13865) \\
{[-0.51324]}\end{array}$ \\
\hline$T R A D E(-2)$ & $\begin{array}{l}0.713448 \\
(0.61164)\end{array}$ & $\begin{array}{l}0.354891 \\
(0.35109)\end{array}$ & $\begin{array}{l}0.164288 \\
(0.18422)\end{array}$ & $\begin{array}{l}-0.186751 \\
(0.09054)\end{array}$ & $\begin{array}{l}-0.065284 \\
(0.15228)\end{array}$ \\
\hline & [1.21514] & [ 1.01482] & [0.78828] & {$[-2.23521]$} & {$[-0.41348]$} \\
\hline $\operatorname{DER}(-1)$ & $\begin{array}{l}-0.122344 \\
(0.35628) \\
{[-0.33447]}\end{array}$ & $\begin{array}{l}-0.175527 \\
(0.27461) \\
{[-0.93041]}\end{array}$ & $\begin{array}{l}0.313691 \\
(0.30167) \\
{[1.31243]}\end{array}$ & $\begin{array}{l}0.117776 \\
(0.13536) \\
{[0.71681]}\end{array}$ & $\begin{array}{l}0.142654 \\
(0.07861) \\
{[1.68314]}\end{array}$ \\
\hline$D E R(-2)$ & $\begin{array}{l}-0.146257 \\
(0.30415) \\
{[-0.48226]}\end{array}$ & $\begin{array}{l}0.103201 \\
(0.20321) \\
{[0.50082]}\end{array}$ & $\begin{array}{l}-0.190313 \\
(0.09764) \\
{[-1.86546]}\end{array}$ & $\begin{array}{l}0.000824 \\
(0.04603) \\
{[0.02242]}\end{array}$ & $\begin{array}{l}-0.084051 \\
(0.08831) \\
{[-1.46357]}\end{array}$ \\
\hline DFDI(-1) & $\begin{array}{l}-0.920534 \\
(0.94536)\end{array}$ & $\begin{array}{l}0.005451 \\
(0.54201)\end{array}$ & $\begin{array}{l}-0.037700 \\
(0.30926)\end{array}$ & $\begin{array}{l}0.387826 \\
(0.13092)\end{array}$ & $\begin{array}{l}0.132063 \\
(0.22205)\end{array}$ \\
\hline & [-0.98756] & [ 0.01075$]$ & [-0.12190] & [2.96240] & [ 0.59474$]$ \\
\hline
\end{tabular}

$\operatorname{DFDI}(-2)$

)

$\begin{array}{lllll}0.413153 & 1.541721 & -0.527458 & 0.041112 & -0.350213\end{array}$ $(1.03027$

) $\quad(0.60520)(0.28831)(0.14225) \quad(0.31219)$

$0.35665]\left[\begin{array}{llllll}2.50851] & {[-1.74527]} & {[0.27964]} & {[-1.20115]}\end{array}\right.$

$\operatorname{DREM}(-1)$

1.600324

$-0.782128$

0.375027

0.31225

0.691502

(3.14641

)

(1.83535)

(1.04160)

(0.45022)

$(0.74565)$

$\begin{array}{lllllll}0.50636] & {[-0.42312]} & {[0.34487]} & {[0.69099]} & {[0.92507]}\end{array}$

$\operatorname{DREM}(-2)$

$\begin{array}{llllll}0.702344 & 2.397251 & -0.764851 & -0.340281 & -0.636245\end{array}$

$(1.42512$

) $\quad(0.83448)(0.52110)(0.19855) \quad(0.34752)$

[

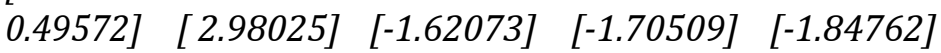

$G D P(-1)$

$\begin{array}{lllll}1.456682 & -2.130406 & 1.040338 & 0.003576 & 0.785205\end{array}$

$(1.65222$

) $\quad(0.94326)(0.54238)(0.22701) \quad(0.33032)$

[

$0.98577][-2.27607]\left[\begin{array}{llll}1.94721] & {[0.01425]} & \text { [2.03223] }\end{array}\right.$

$G D P(-2)$

$\begin{array}{lllll}0.187083 & 2.422839 & -0.201224 & -0.314357 & -0.183285\end{array}$ 


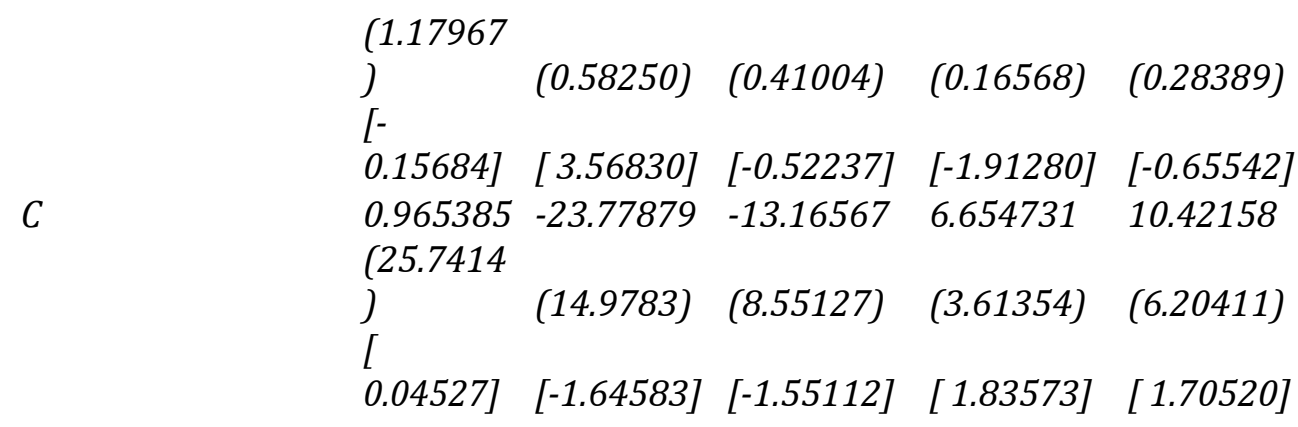

\begin{tabular}{llllll}
\hline$R$-squared & 0.656482 & 0.808634 & 0.632480 & 0.656917 & 0.753440 \\
Adj. R-squared & 0.569445 & 0.725903 & 0.597441 & 0.470752 & 0.660321 \\
Sum sq. resids & 104.9667 & 35.35849 & 11.51233 & 2.062981 & 5.935027 \\
S.E. equation & 4.581848 & 2.659266 & 1.517388 & 0.642337 & 1.089498 \\
F-statistic & 1.554033 & 2.973619 & 1.368821 & 1.556813 & 2.912481 \\
& - & & & & \\
Log likelihood & 37.75145 & -29.04661 & -20.06966 & -6.315523 & -14.76928 \\
Akaike AIC & 6.093931 & 5.005827 & 3.883707 & 2.164440 & 3.221160 \\
Schwarz SC & 6.625086 & 5.536981 & 4.414862 & 2.695595 & 3.752315 \\
Mean dependent & 74.06261 & 0.750000 & 0.176113 & -0.447982 & 3.734206 \\
S.D. dependent & 5.358510 & 5.081370 & 1.703844 & 0.743815 & 1.654179 \\
& & & & & \\
\hline
\end{tabular}

Determinant resid covariance

(dof adj.)

Determinant resid covariance

Log likelihood

Akaike information

criterion

Schwarz criterion
0.502625

0.001501

$-61.50325$

14.56291

17.21868

\section{Granger Causality}

Granger causality is a test used to find out if one variable can be used to predict another. It also shows the course of the relationship in the sense that it is one-sided or two-sided. The results for Granger Causality support the basic hypothesis that DER does not cause Granger Trade. Granger causality does not show a two-way causality between trade as a percentage of GDP and the Euro / ALL exchange rate. 
Finally, it should be said that this study has its limitations that may affect the accuracy of the results such as the small number of observations and the fact that the variables have different levels of stationarity, therefore the parameters may be shifted.

\section{Conlusions}

This analysis was performed by applying the econometric VAR approach and using data on trade as a percentage of GDP, Euro / ALL exchange rate, foreign direct investment, economic growth and remittances.

The period in which the study was conducted is 2000-2018 and the technique used was the VAR model to measure the long-run relationship of macroeconomic variables.

According to the VAR model there is no stable link between the exchange rate and trade. It should be noted that the model suffers from a lack of data and does not give a very consistent conclusion.

\section{Bibliography}

[1] An overview of remittances. (2019). Retrieved from Bank of Albania: https://www.bankofalbania.org/rc/doc/Fletepalosje_Remitancat_Shqip_201 9_14709.pdf

[2] Bahmani, O., \& Kutan, M. (2006). The J-Curve in the Emerging Economies of Eastern Europe. EMG Working Paper Series .

[3] Cakrani, E. (2014). The Real Exchange Rate and its impact on the economy: The case of Albania. PHD dissertation, University of Tirana .

[4] Hacker.R.S ; Hatemi-J.A. (2004). The effect of exchange rate changes on trade balances in the short and long run. The Economics of Transitions, 777-799.

[5] HODA, B. (2013). The Role of Exchange Rates in International Trade Models: Does the Marshall-Lerner Condition Hold in Albania? Working Paper 13 (52)

[6] Salko, D., \& Osmani, M. (2002). Several Macroeconomic Patterns for Albania Economy over the Transition Period. The Second National Conference of Bank of Albania .

[7] Sojlli, E., \& Shtylla, D. (2006). "Forecasting the Balance of Payment". Discussion material of Bank of Albania . 